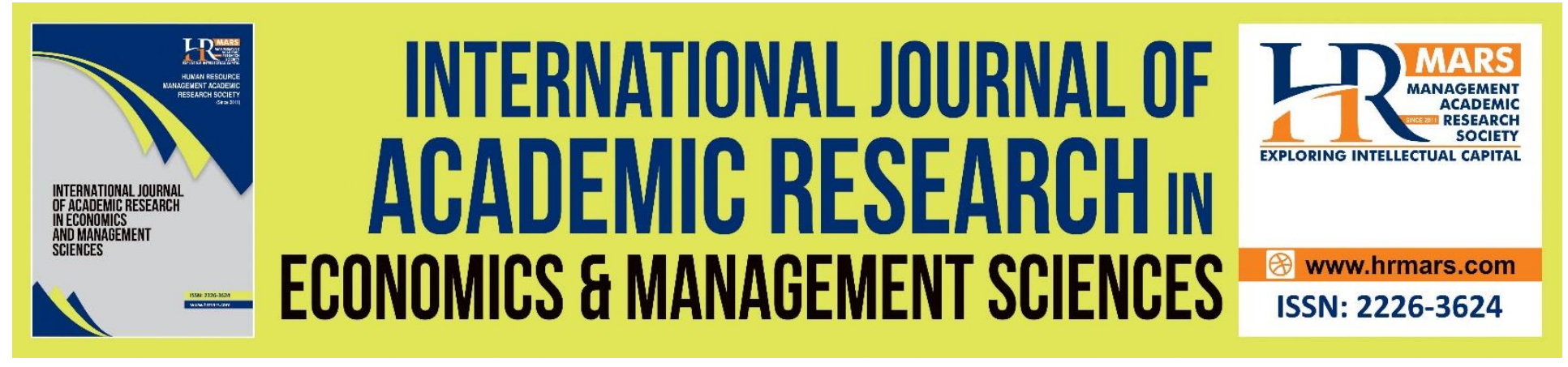

\title{
A Mixed-Method Study on Innovation Capability Enhancing through Entrepreneurial Education: New Normal Perspective
}

Jianqiang Lei, Oo Yu Hock

To Link this Article: http://dx.doi.org/10.6007/IJAREMS/v9-i3/7861

DOI: 10.6007/IJAREMS/v9-i3/7861

Received: 20 July 2020, Revised: 10 August 2020, Accepted: 20 September 2020

Published Online: 30 October 2020

In-Text Citation: (Lei, \& Hock, 2020)

To Cite this Article: Lei, J., \& Hock, O. Y. (2020). A Mixed-Method Study on Innovation Capability Enhancing through Entrepreneurial Education: New Normal Perspective. International Journal of Academic Research in Economics \& Management Science. 9(3), 1-20.

Copyright: (c) 2020 The Author(s)

Published by Human Resource Management Academic Research Society (www.hrmars.com)

This article is published under the Creative Commons Attribution (CC BY 4.0) license. Anyone may reproduce, distribute, translate and create derivative works of this article (for both commercial and non-commercial purposes), subject to full attribution to the original publication and authors. The full terms of this license may be seen at: http://creativecommons.org/licences/by/4.0/legalcode

Vol. 9, No. 3, 2020, Pg. 1 - 20

http://hrmars.com/index.php/pages/detail/IJAREMS

JOURNAL HOMEPAGE

Full Terms \& Conditions of access and use can be found at http://hrmars.com/index.php/pages/detail/publication-ethics 


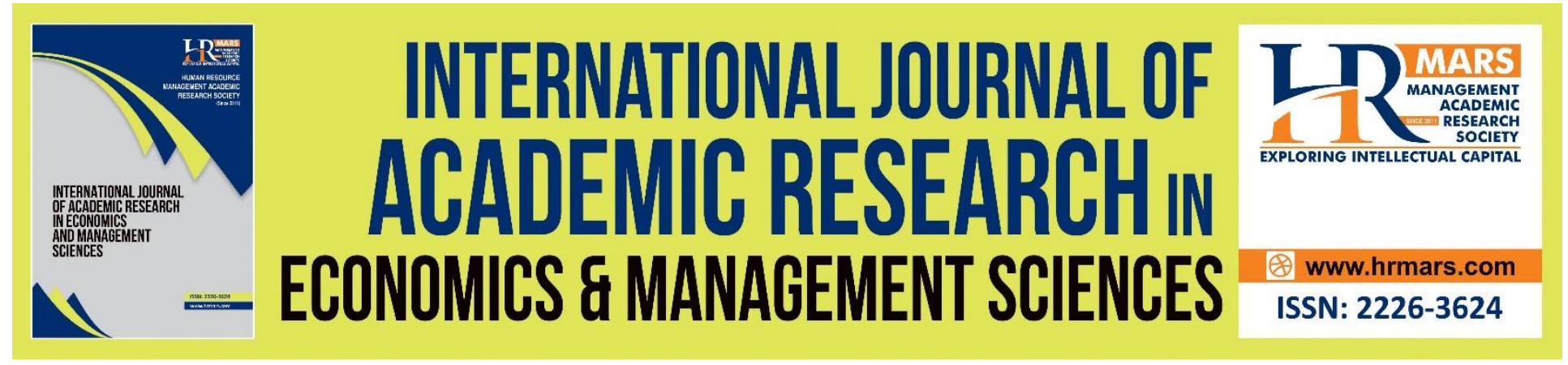

\title{
A Mixed-Method Study on Innovation Capability Enhancing through Entrepreneurial Education: New Normal Perspective
}

\author{
Jianqiang Lei ${ }^{1}$, Prof Dr Oo Yu Hock ${ }^{2}$ \\ ${ }^{1} \mathrm{PhD}$ Candidate, Binary University of Management \& Entrepreneurship, Malaysia, ${ }^{2}$ Professor, \\ Asia e University (AeU), Malaysia \\ Email: jameslei112007@gmail.com
}

\begin{abstract}
The outbreak of the COVID-19 pandemic crisis in 2020 is similar to other crises, such as natural disasters, war, macroeconomic mismanagement, and its economic shock has brought great influence to enterprises all over the world. The crisis will lead to a large number of small and medium-sized enterprises (SME) bankruptcy and social unemployment tide. The tense trade war and ideological conflict between China and the United States before the outbreak have brought China's economic development into a severe bottleneck period. The main objective of this study is to analyze the influence of entrepreneurship education on innovation capability among undergraduate students in Guangxi, China. The mixed-method research design is utilized in this study, the quantitative data of 400 senior undergraduates from 3 universities in China were collected by questionnaires, the proposed data analysis has adopted by CB-SEM. A qualitative sample of the in-depth interview was identified as 15 and Nvivo software was utilized for data analysis, including 12 students and 3 instructors from three universities. The current international competitiveness is mainly focused on the technical talents and innovation capability, this study referenced the Triple Helix Model of Innovation that government, university, and industry play the important roles in the innovation ecosystem. The findings revealed the institutional environment and supporting infrastructure have a significant impact on student's innovation capability, and entrepreneurial capital obtained from entrepreneurship education program is important for the cultivation of innovation capability. This research makes significant theoretical and practical implications to enrich the existing literature of the relationship of entrepreneurship education and innovation capability, and the policymakers of government and universities should encourage the innovation-driven entrepreneurship education practices in the new normal economic environment.
\end{abstract}

Keywords: Entrepreneurship Education, Innovation Capability, Entrepreneurial Capital, International Competitiveness, New Normal 


\section{Introduction}

In 2020, the COVID-19 pandemic plunged the global economy into its deepest recession since World War II (World Bank, 2020). The pandemic could destroy our community in multiple ways, including weakening investment, leaving behind long-term economic trauma, unemployment, human capital damage, school education loss, and global trade and supply chain disruptions. A slowdown in productivity growth since the global financial crisis and the combined effects of COVID-19 could have a profound impact on progress towards social-economic development goals (Pazarbasioglu, 2020). The impact of the epidemic on the Chinese economy is mainly two aspects: in the short term, the global economic weakness caused by the epidemic poses a severe challenge to export trade. In the long term, the epidemic has accelerated the reshuffle of the global industrial chain, forcing China to accelerate the transformation of its economic growth model, should not be content with the achievements of low-cost manufacturing, but strive to upgrade automation, digitization, and intelligence.

Before the outbreak of the epidemic, the nature of China-US relations began to change fundamentally, from international trade partnership to strategic competitors, the "new cold war" between China and the United States is imminent. The contradiction between the two countries has risen from finance and trade, science, and technology to cultural, political, and ideological levels, resulting in a limited supply of chips to Chinese technology firms such as Huawei, and Chinese app Tik Tok, WeChat will be removed from the American app store. In this context, both global manufacturing and supply chains will be severely affected, resulting in increased unemployment and slow economic recovery. Because of China's long-term dependence on lowcost manufacturing and export trade, so the bankruptcy of a large number of manufacturing enterprises has exacerbated the unemployment rate among university graduates.

Since 1999, China began to expand higher education, the number of students in higher education institutions has more than eight times, from 1 million in 1998 to 8.7 million in 2020. According to the report of the National Bureau of Statistics of China, the unemployment rate in the National Urban Survey remained around 5\% from 2014 to 2018. Under the global pandemic, China's State Council announced that the urban survey unemployment rate in 2020 has risen to $6 \%$. In such a situation, entrepreneurship education is expected to make a large contribution to creating an impetus for the economy and increasing community income (Idris et al., 2018).

In 2002, the university entrepreneurship education was officially launched in China, because entrepreneurship is an important means to serve economic development and relieve employment pressure, entrepreneurship education is gradually popularized in colleges and universities. Since then, the Chinese government proposed a "mass entrepreneurship, mass innovation" development strategy at the Davos Economic Forum in 2014. This is an important embodiment of social development strategy, the value of entrepreneurship education in colleges and academia has attracted wide attention, and focus on innovation-oriented. However, the history of innovation and entrepreneurship education in Chinese universities is short, still at the early development stage, and lack of systematic and practical effectiveness. There is a need to deeply explore the key issues in the process of innovative entrepreneurship education. Innovation and entrepreneurship education in Chinese universities have become an important part of Chinese higher education (Lu \& Zhang, 2018).

Since 2012, China's economy has shown a significant slowdown, with growth rates falling from more than 10 percent (before the 2007-2009 financial crisis) to about 7 percent in 2014, showing 
that China is entering the New Normal era. After that COVID-19 have a profound impact on the economy and education model through multiple channels, undermining national competitiveness, and social productivity. Firstly, weaker investment and trade, because the investment play important role in promoting productivity growth. Secondly, human capital loss and labor market transfer, education remains a key driver of growth in social productivity and international competitiveness. Many schools and universities around the world have adopted online education tools of the blended learning approach to mitigate this pandemic shocks of the education industry. At least 50 million students from elementary to high school had signed up for its online teaching programs as of February 10, 2020 (Bloomberg, 2020). Obviously, many countries are aware of the urgent need to make use of high-quality online education and training, so the traditional inefficient entrepreneurship education model should be changed as well. There are distinct blended learning models suggested by some researchers and educational think-tanks, these models include the face-to-face driver, Rotation model, Flex model, Labs, Self-blend model, and Online driver (Friesen, 2012). Due to entrepreneurship education as an important way to cultivate innovative entrepreneurship talents and increase social productivity, there is an important significance to study the relationship between stakeholders of innovation activities. According to the Triple Helix Model of Innovation that three main stakeholders in the entrepreneurship ecosystem: government, university, and the industry are very important to the innovation (Etzkowitz \& Leydesdorff, 1995).

The report of China's university student's entrepreneurial intention survey in 2018 found that undergraduate student's entrepreneurial intention was much higher than graduate students and other educational levels, and it was the main group of university entrepreneurship. The main objective of this study is to investigate the influence of entrepreneurship education on innovation capability among Chinese undergraduate students. The world's academic community has done a lot of research in entrepreneurship education, but lack of comprehensive research on the factors of entrepreneurship education impact student's innovation capabilities, especially for the research on entrepreneurial capital and practical teaching model. This research aims to fill this gap by an empirical study with a mixed-method research design.

\section{Literature Review}

The literature has carried on a lot of research on entrepreneurship education, such as entrepreneurial ability, entrepreneurial culture, innovative spirit, and entrepreneurial intention (Pittaway \& Cope, 2006; Lorz et al.,2013; Sirelkhatim \& Gangi, 2015; Nabi et al., 2017; Bazan et al., 2020). The previous literature on the field of innovation is mainly focused on national innovation, innovative city, and enterprise innovation levels, but there was a lack of studies seeking to identify and understand potential relationships between entrepreneurship education and individual innovation capability. The triple-helix model of innovation created from the viewpoints of economy and politics is undoubtedly the most famous in interpreting the model of entrepreneurship education from the national, regional, and university relations (Etzkowitz \& Leydesdorff, 2000). Based on the triple-helix innovation model, this study further analyzes the interaction between the stakeholders of government, university, and industry, and the entrepreneurial capital generated to support the student entrepreneurial activities. In a broad sense, entrepreneurial capital includes human capital and social capital available to entrepreneurs. 
Romer (1998) proposed the Endogenous Growth Model to identified the businesses and workers rely on human capital investment to improve competitiveness, profits, and rewards. Wu (2018) stated entrepreneurial education is a creative education, the establishment of enterprises is not the real goal of entrepreneurial education, its ultimate goal is to cultivate learner's innovation, entrepreneurial spirit, ability, and literacy so that learners have the ability to achieve their own goals, rather than directly set a certain goal for them.

The theory of innovation capability interaction holds the innovation is an individual's behavior in a particular situation, prior experience, personal factors, environmental factors will influence innovation behavior, and then produce innovation results (Woodman \& Schoenfeldt, 1990). In China's business world, social capital implies preferential treatment to exchange and access limited resources, reliable information, and controlled infrastructure. Altshuller (1946) created the TRIZ theory and stated that is a theory of inventive problem-solving. Wang (2017) applied the method of TRIZ decomposition to analyze the problems of cultivating college students entrepreneurial innovation education and constructing the concept model of developing innovation ability, the finding suggests the innovation spirit, the innovative thinking, the entrepreneurial activity, and the entrepreneurial capacity has a positive effect on the entrepreneurial innovation ability.

Entrepreneurship education program is an academic education or formal training interventions that share the broad objective of providing individuals with the entrepreneurial mindsets and skills to support participation and performance in a range of entrepreneurial activities, which tend to focus on building knowledge and skills about or for the purpose of entrepreneurship (World Bank, 2014). From the perspective of higher education, the entrepreneurship education model includes the philosophical understanding of entrepreneurship education and the fiveelement conceptual model of teaching objectives, contents, methods, evaluation, and target learners in entrepreneurship education projects (Fayolle \& Gailly, 2008).

H1: Entrepreneurship Education Program has a significant relationship on innovation capability. Institutional environment of a country or region is made up of local rules and conditions, in which local individuals or organizations have legitimacy and support only when they operate (Baumol, 1993). And institutions and rules have always affected entrepreneurial activities, different institutions and rules will cause different results of entrepreneurial activities, so entrepreneurship research should pay special attention to the role of the institutional environment. Scott (1995) stressed that the institution can make the society stable and have cognitive, normative, and regulatory restraint mechanisms and activities, on the basis of this theory logic he proposed three kinds of restriction behaviors: regulation, normalization, and cognition.

H2: Institutional environment has a significant relationship on innovation capability.

Supporting infrastructure consists of physical, institutional, and organizational structures that support economic activities such as entrepreneurship. Thus, the infrastructure of entrepreneurial activity exists outside focal firms, and supports the opportunities themselves, people seize and create opportunities, means to create opportunities and an enabling environment. Van de Ven 
\& Garud (1989) stressed the perspective of the social system argues that the three functions of the social system provide the infrastructure essential to the emergence of the industry: the functions of the technical instruments, the functions of resource procurement, and institutional legitimization and governance.

H3: Supporting infrastructure has a significant relationship on innovation capability.

Peer input refers to peer consultations, which often means interactive work products during the development of an evolving institution, providing open communication of data, insights, and ideas. Harris (1995) argued peer relationships also have a double impact on innovation ability. On the one hand, peer relationship will hinder the performance of individual innovation ability. The theory of group socialization development shows that peer groups promote children's social development, mainly using the assimilation mechanism, which means that individuals inhibit their own ideas different from their peers in order to integrate peer grouped, so the individual's innovation ability will be affected by the "Crowd psychology ".

H4: The relationship between the institutional environment and innovation capability is significantly influenced by peer input.

H5: Peer input significantly moderates the relationship between supporting infrastructure and innovation capability.

The Innovation-driven Innovation and Entrepreneurship Education has the most original innovation elements, which is the education model with the most primary innovative output. The essential difference between these three modes is the difference in the content of original innovative elements (Chen, 2018). Based on the triple-helix model innovation theory, this study proposed that the university's entrepreneurship education program provides entrepreneurial human capital for students, while the university works with the government and industry to form an innovation network to provide entrepreneurial social capital for students through the institutional environment and supporting infrastructure, peer input may be moderating affect the relationship between social capital and innovation, the empirical analysis will be used to test the following conceptual framework of innovation-driven entrepreneurship education to fill theoretical gaps. 


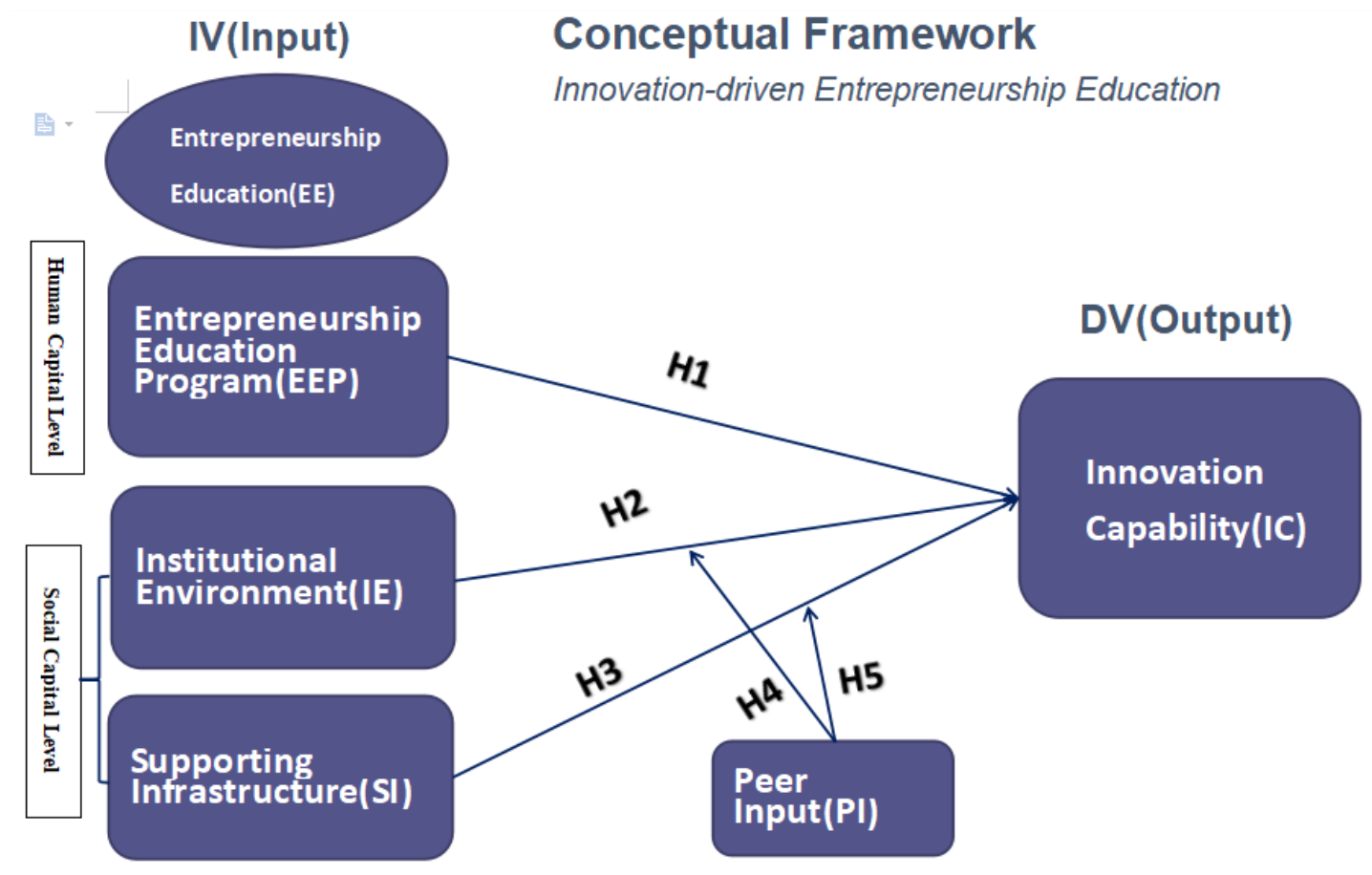

\section{Methodology}

In order to collect the most complete information as much as possible and ensure a high degree of rigor, this study selected a mixed-method research format (Brantlinger et al., 2005; Lund, 2012; Wyatt, 2015). The above research aims to provide strong evidence for the innovation capability research model. Therefore, the mixed design adopted in-depth view from stakeholders of entrepreneurship education.

Research approach: this study is based on the design of mixed-method research combining inductive and deductive reasoning, which provides a theoretical basis, including the main components of the topic: the impact of entrepreneurship education on innovation capability (Creswell et al., 2003). It also guides the development of research objectives and assumptions. In this study, the epistemology position of pragmatism was chosen, because this study investigated the real influencing factors and improvement experience that led to the poor effect of entrepreneurship education output.

Research design: the reason for using a combination of quantitative and qualitative methods for mixed-method research is to understand the degree of relevance of innovation capability because of the immediacy and communication skills of students and teachers and find meaning in this relationship. The sequential interpretation design of this study "prioritizes quantitative data and combines the two methods used in the interpretation phase of the study " (Plano-Clark $\&$ Creswell, 2008). Among these data collection methods, questionnaires and semi-structured interviews are the most common. The survey instrument will be used to answer the following research questions. 

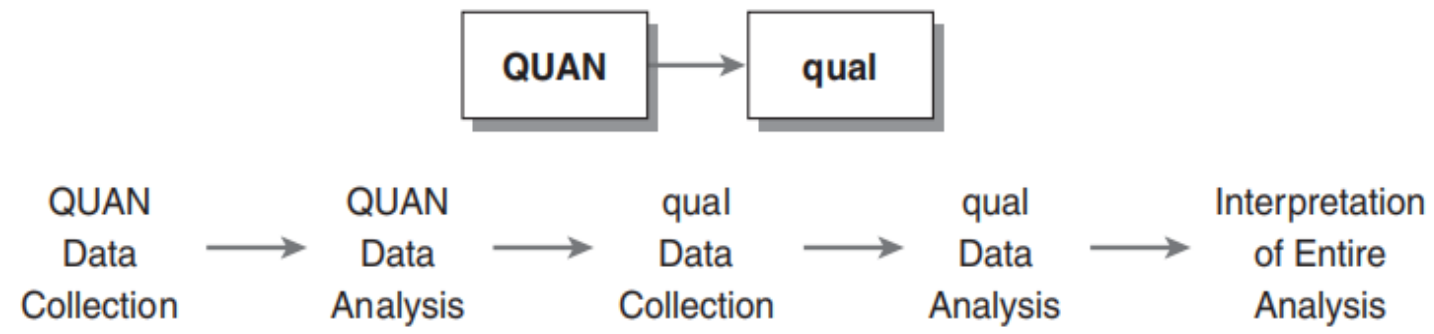

Figure 1: Sequential Explanatory Design

Sampling technique: Probabilistic sampling is simple random sampling, which means that each element in the group of interest has an equal and independent chance of being selected (Saunders et al ., 2009). In this study, the probability cluster and non-probability convenience sampling method will be used to obtain the information of the respondents from two different sources: the probability sampling technique of the students' senior students was a questionnaire investigated by the professional departments and entrepreneurship centers of the students' university. Convenience technology chooses different major student, the instructor of entrepreneurship project, or entrepreneurship competition for the semi-structured interviews. The total population of senior (Year 3-4) undergraduates in 3 selected Chinese universities is 15365 students. Yamane (1967) provides a simplified formula to calculate sample sizes. A 95\% confidence level and $P=5 \%$ are assumed for equation. Where $n$ is the sample size, $N$ is the population size 15365, and e is the level of precision. When this formula is applied to the above sample, we get the equation to calculate a sample size of this study is $n=N /\left[1+\mathrm{Ne}^{2}\right]$, the sample size: $n=394$ respondents.

The sampling method of qualitative research basically depends on the purpose of the study, purposeful sampling is without a common sampling strategy. In this type of sampling, participants were selected or sought according to preselect criteria based on research questions. Guest (2006) proposed that saturation often occurs in a homogeneous group of approximately 12 participants. In this study, a qualitative sample of semi-structured interviews was identified as 15 , including 12 students and 3 instructors from three Chinese universities. Each university selected an average of 4 students and 1 instructor to ensure the equality and accuracy of the sample.

Scale measurement: Prior to large-scale quantitative research, a pilot study was conducted to examine the reliability of scale measurements measured for structural internal consistency. Since the initial scale removed some items after exploratory factor analysis, for validation with a more independent and diverse sample of the revised innovation capability scale (Churchill, 1979), this study performed confirmatory factor analysis (CFA) of the scale by using Smart PLS 3.0 software. The model of confirmatory factor analysis are shown in Figure 2 and $R^{2}>0.6$ indicates good model fit. 


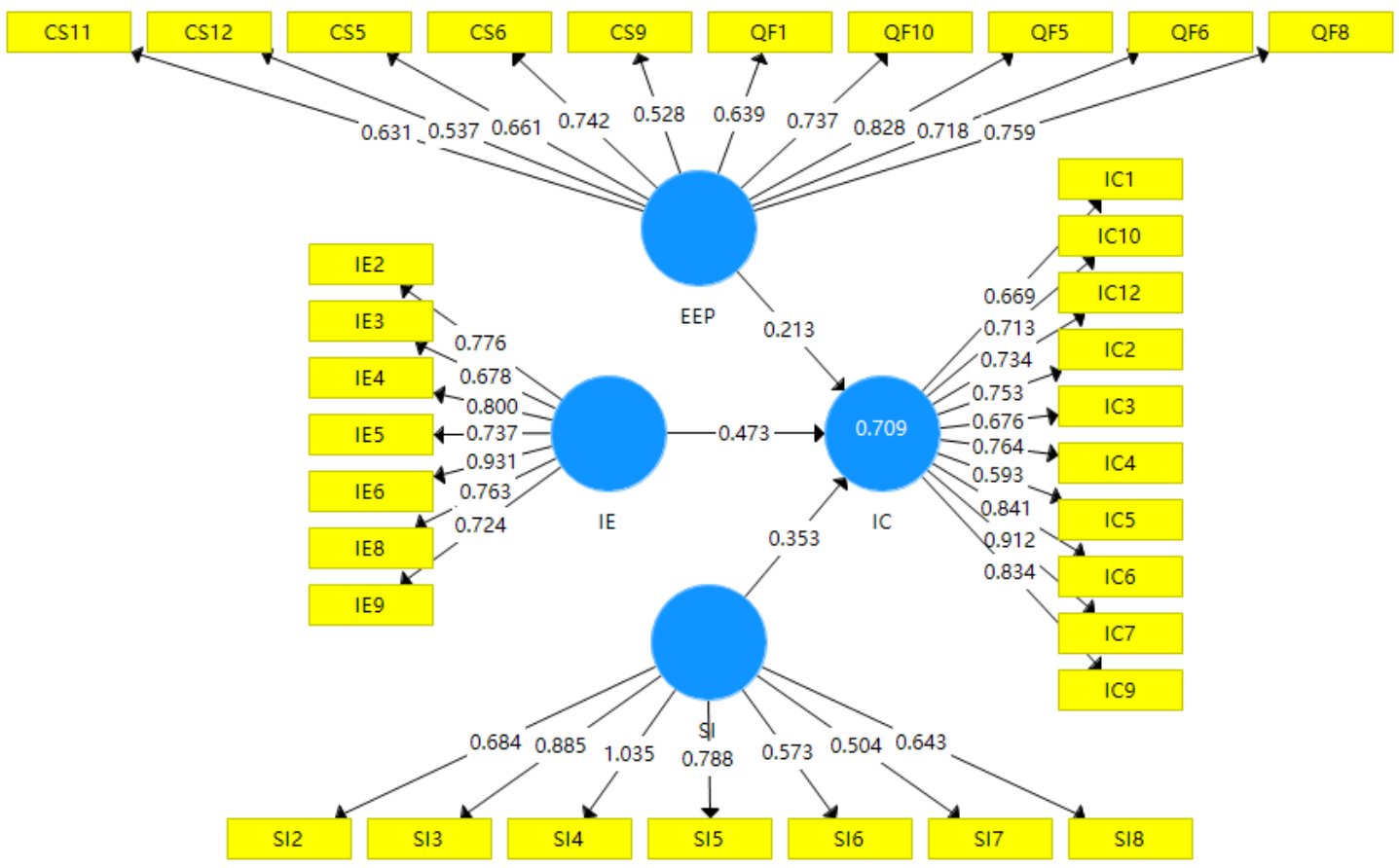

Figure 2: The Measurement Model of Confirmatory Factor Analysis

Table 1 shows that the path coefficients of all latent variables are bigger than 0.5 (factor loading). Through calculation, the combined reliability (CR) values of the innovation capability scale bigger than 0.7 , and the average variable extraction ( $A V E$ ) value is greater than 0.5 , which indicates the convergent validity is good.

Table 1: Confirmatory Factor Analysis of Innovation Capability Scale

\begin{tabular}{|c|c|c|c|c|}
\hline Items & Factor Loading & CR & AVE & R square \\
\hline IC 1 & 0.669 & \multirow{10}{*}{0.927} & \multirow{10}{*}{0.564} & \multirow{10}{*}{0.709} \\
\hline IC 2 & 0.713 & & & \\
\hline IC 3 & 0.734 & & & \\
\hline IC 4 & 0.753 & & & \\
\hline IC 5 & 0.676 & & & \\
\hline IC 6 & 0.764 & & & \\
\hline IC 7 & 0.593 & & & \\
\hline IC 8 & 0.841 & & & \\
\hline IC 9 & 0.912 & & & \\
\hline IC 10 & 0.834 & & & \\
\hline
\end{tabular}

\section{Results and Discussion}

All 400 participants screened into the study were senior undergraduate students. Among them, 301 respondents are female, the other 99 are male, this relates to the universities and majors selected for the survey. The quantitative data of the survey were transferred from the Excel 
spreadsheet to the SPSS 20 data analysis system at the end of the data collection period. Because there are many items in this study, we carried on the descriptive statistical analysis to each variable, using the data analysis from each item mean, standard deviation, variance. Skewness and kurtosis values were obtained to assess non-normality (Hair et al .,2013). Therefore, the results show that the skewness and kurtosis of most items are between -1 and 1 , which indicates that the non-normality of the data is not a problem in this study, the result is shown in Table 2.

Table 2: Descriptive Statistics of Variables

\begin{tabular}{llllll}
\hline \hline Variables & Mean & \multicolumn{2}{l}{ Std. Deviation } & Variance & \multicolumn{2}{l}{ Skewness } & Kurtosis \\
\hline EEP & 3.6400 & .79048 & .625 & -.082 & -.174 \\
IE & 3.8982 & .72540 & .526 & -.252 & -.253 \\
SI & 3.7859 & .74450 & .554 & .028 & -.447 \\
IC & 3.8903 & .71516 & .511 & -.212 & -.224 \\
PI & 3.5746 & .75486 & .570 & .229 & -.215 \\
\hline
\end{tabular}

In this study, the path analysis method of CB-SEM is used to analyze the relationship between the variables of the theoretical model. The AMOS 21 analysis results and data of the model adaptation are shown in figure 3 . The $R^{2}$ and adjustment $R$ square are show the fitting degree of the model equation in regression analysis, and Lu (2000) pointed out that greater than 0.6 indicates fitting is good, the innovation capability is demonstrated by a large effect $(0.820)$ with independent variables in this study.

Figure 3: The Path Analysis Model

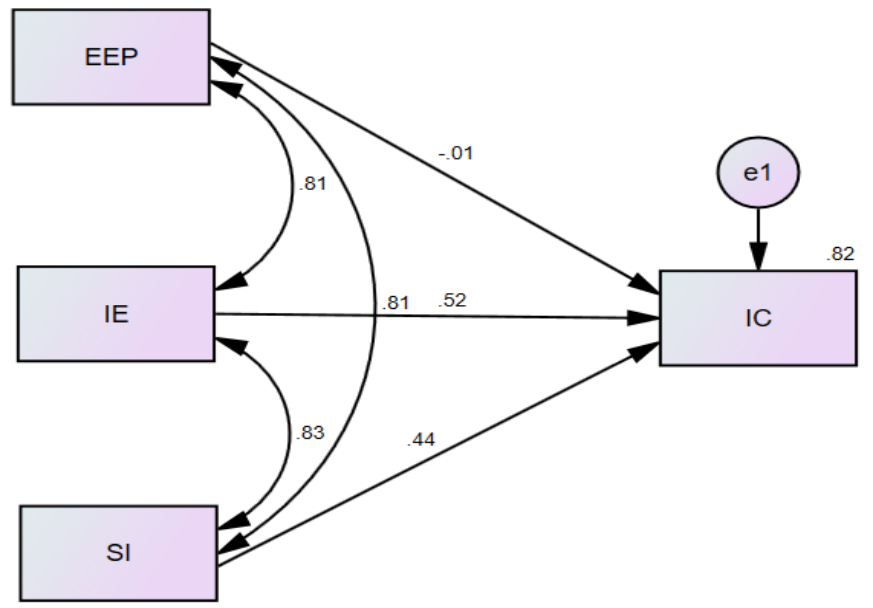

The multivariate linear regression were used to test the hypotheses, and the two different effects of adjusting variables are analyzed. To analyze the mechanism of entrepreneurship education on innovation capability, we should first analyze the direct effect of entrepreneurship education on innovation capability. In this study, entrepreneurship education program, institutional environment, supporting infrastructure as independent variables, innovation capability as the dependent variable, and gender, major, family financial background, and entrepreneurial experience as the control variables were put into the regression equation and conducted the multiple regression analysis. The results of the analysis are shown in Table 3 , the adjusted $\mathrm{R}^{2}$ 
values are 0.817 indicated the model fitting effect is good and the $F$ values are all significant at 0.001 level. The relationship between entrepreneurship education program (EEP) and innovation capability is not positively significant $(\beta=-.011, p>0.05)$, but the influence of the other two independent variables on the innovation capability of the dependent variable, institutional environment $(\beta=0.505, p<0.01)$ and supporting infrastructure $(\beta=0.452, p<0.01)$ have significant positive effects on innovation capability. All the VIF in the model are less than 5 and the tolerance is greater than 0.1, there are no serious collinearity problems (Zhang, 2016). To sum up, the hypothesis testing results do not support $\mathrm{H} 1$, but support hypothesis $\mathrm{H} 2$ and $\mathrm{H} 3$. This result is consistent with Walter (2015) claimed that entrepreneurship education stimulates entrepreneurs activities that entrepreneurship incubates in entrepreneurial-friendly institutional environments.

Table 3: The Results of Multivariate Linear Regression Analysis

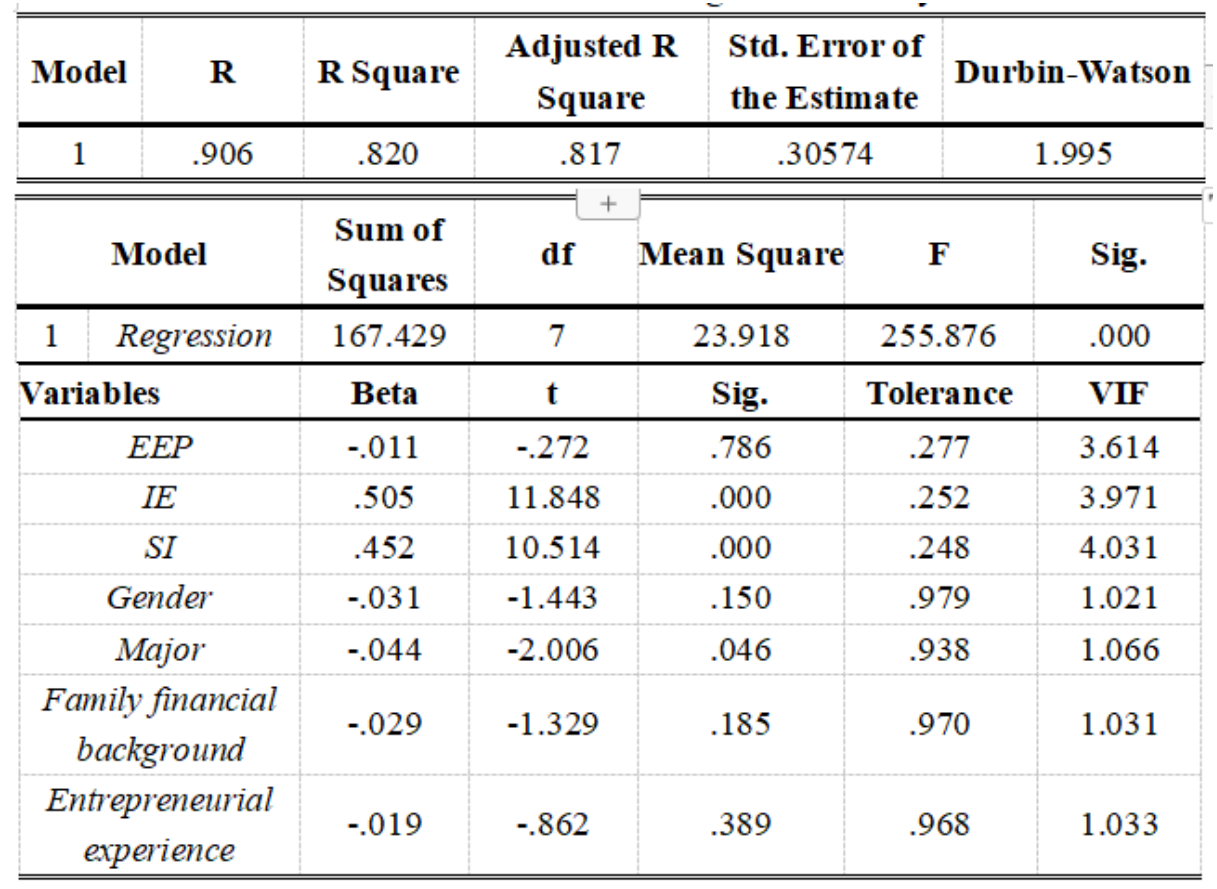

To further demonstrate the role of peer input in moderating the relationship between institutional environment and innovation capability, this study used AMOS 21 to draw a model diagram of moderating effect as Figure 4 and Bootstrap method 2000 times to detect the significance of moderator. The results shows that interaction of peer input and institutional environment $P$-value is 0.243 , confidence interval $(-0.448,0.695)$, the moderating impact is not significant. 
Figure 4: The Model of Peer Input Moderating Effect Between IE and IC

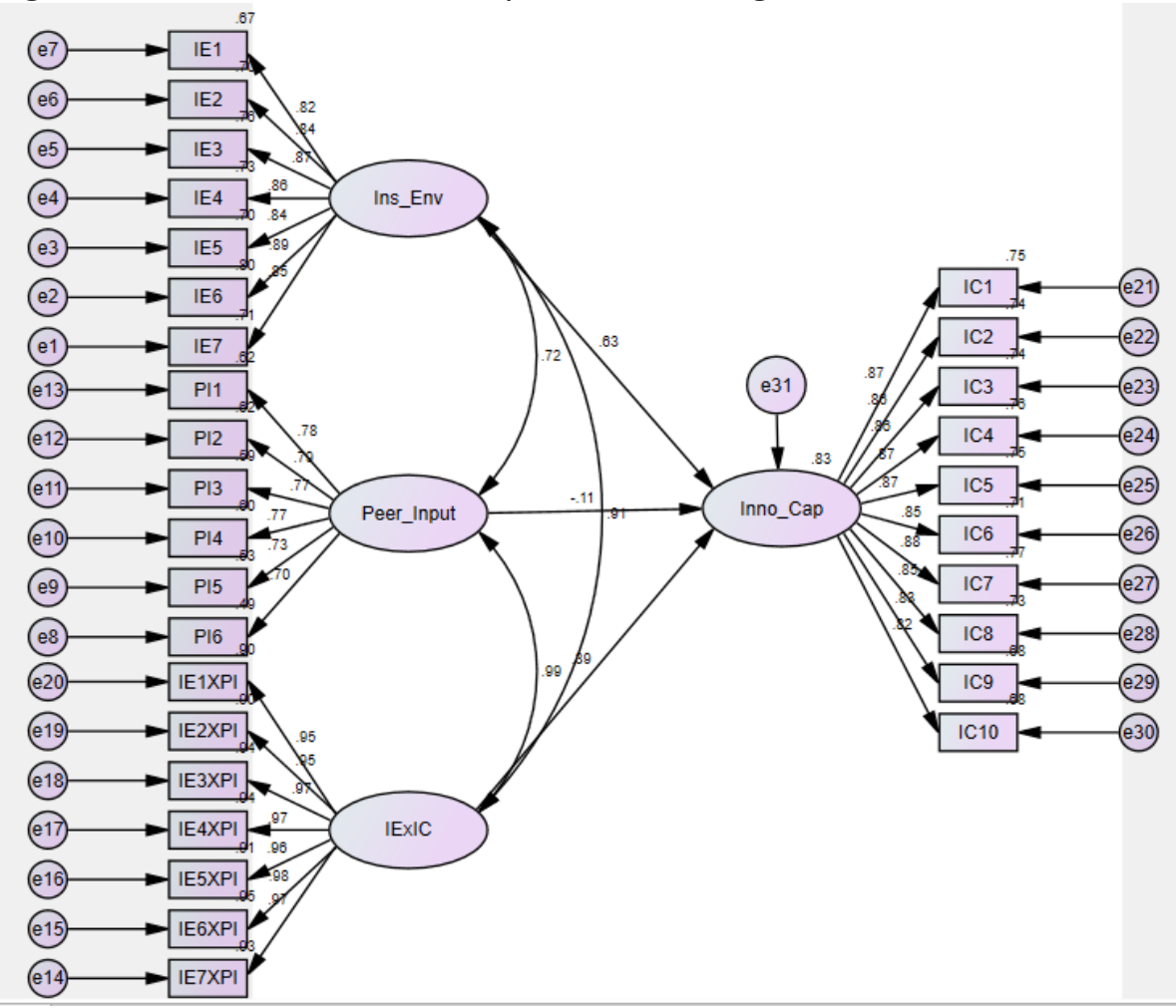

To demonstrate the role of peer input in regulating the relationship between supporting infrastructure and innovation capability, this study also used the AMOS 21 to draw a moderating effect model diagram as figure 5 below and Bootstrap method 2000 times to test the significance of moderating variable. The results show that $P$ value of interaction between peer input and supporting infrastructure is $0.001(p<0.01)$, confidence interval $(0.319,0.969)$, there is a positive and significant moderating effect, and the hypothesis $\mathrm{H} 5$ is supported. This result supports the view of Heger and Veith (2015) stated given the importance of entrepreneurship, public and private organizations are interested in the topic of mechanisms or infrastructure to support entrepreneurship. 
Figure 5: The Model of Peer Input Moderating Effect Between SI and IC

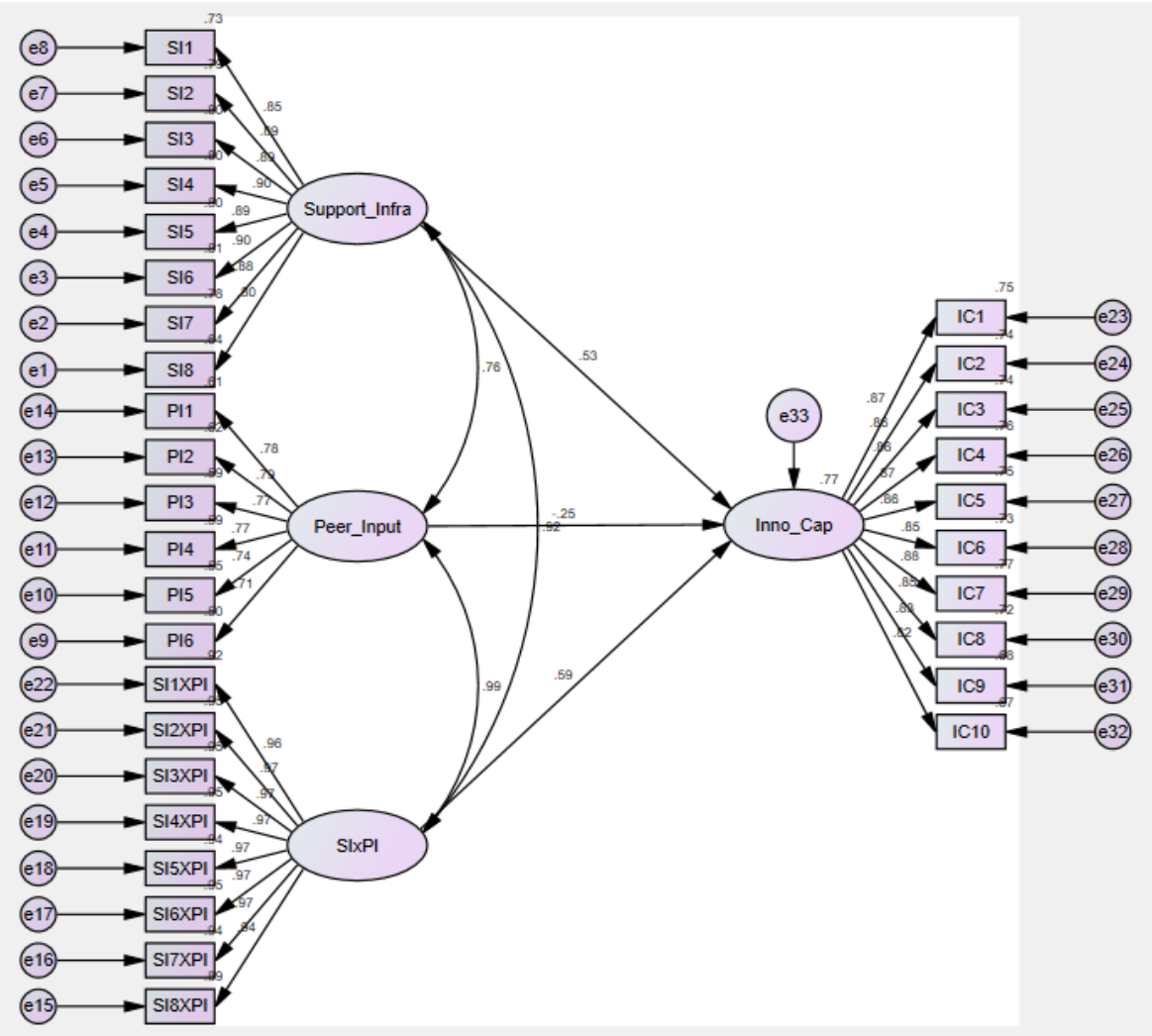

The practice of innovative entrepreneurship education for university students is a complex process of dynamic development, the factors that affect the innovation capability of undergraduate students are diverse and complicated, and the relationship between some factors is difficult to completely reflect in quantitative research. Based on the grounded theory, this paper used the qualitative research method of in-depth interview to survey 15 interviewees (12 students and 3 mentors) for deeply study. The Nvivo 12 qualitative analysis software were used to review and encode the data and to find the frequency of themes occurrence from all individual interview transcription. This study identified themes from the data sources and considered information about patterns, clusters, and code families associated with each research issue (LoBasso, 2014).

Figure 6: Interview Transcription World Cloud of Nvivo 12

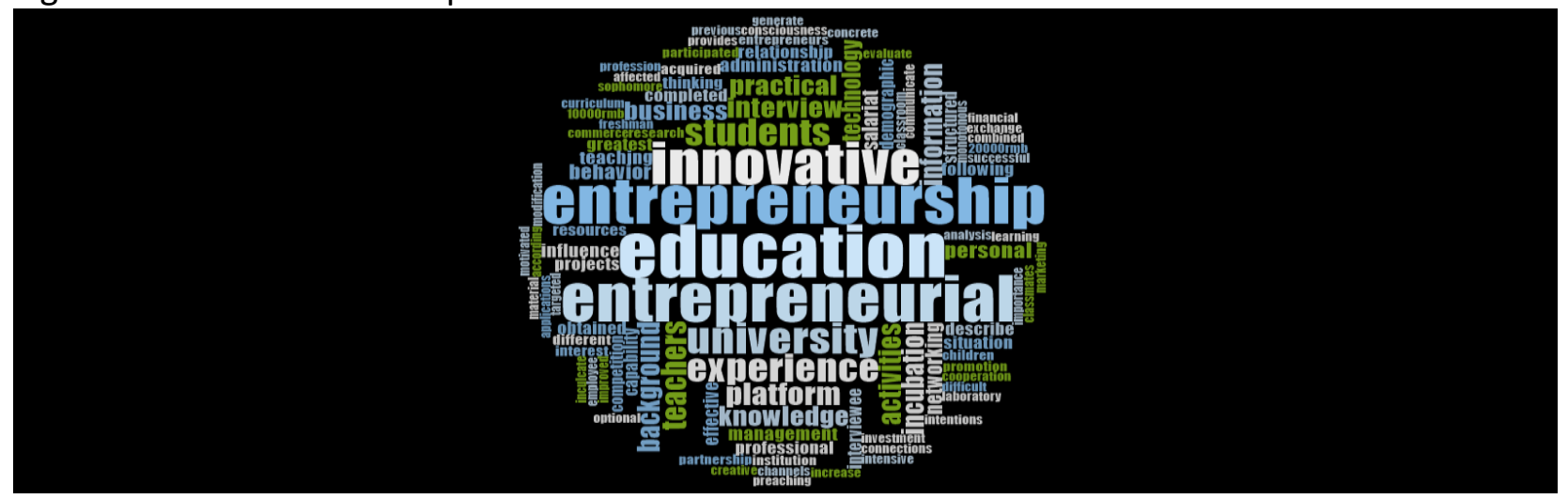


The qualitative data analysis of this embedded mixed research approach involves examining the full-text answers to open survey questions. common topics were extracted from the participant answers and grouped according to the research questions guiding this study (Kirby, 2011). From the overall demographic data of the interviewees, the geographical distribution is reasonable, and the proportion of gender, professional and entrepreneurial experience is equilibrium, which accords with the criteria of selecting qualitative research interview samples as Table 4 below.

Table 4: Distribution of Interviewees and Demographic Information

\begin{tabular}{|c|c|c|c|c|c|}
\hline $\begin{array}{l}\text { Participan } \\
\text { t Code }\end{array}$ & $\begin{array}{l}\text { Participant } \\
\text { Classification }\end{array}$ & $\begin{array}{l}\text { Gende } \\
r\end{array}$ & Major & $\begin{array}{l}\text { Location } \\
\text { Universit } \\
\text { y }\end{array}$ & $\begin{array}{l}\text { Entrepreneuri } \\
\text { al Experience }\end{array}$ \\
\hline P 1 & $\begin{array}{l}\text { Senior } \\
\text { student }\end{array}$ & Male & $\begin{array}{l}\text { Business } \\
\text { Manageme } \\
\text { nt }\end{array}$ & GNU & 3 Years \\
\hline P 2 & $\begin{array}{l}\text { Senior } \\
\text { student }\end{array}$ & $\begin{array}{l}\text { Femal } \\
\text { e }\end{array}$ & $\begin{array}{l}\text { Business } \\
\text { Manageme } \\
\text { nt }\end{array}$ & GNU & 1 Year \\
\hline P 3 & $\begin{array}{l}\text { Senior } \\
\text { student }\end{array}$ & $\begin{array}{l}\text { Femal } \\
\text { e }\end{array}$ & $\begin{array}{l}\text { Business } \\
\text { Manageme } \\
\text { nt }\end{array}$ & GNU & 3 Years \\
\hline P 4 & $\begin{array}{l}\text { Senior } \\
\text { student }\end{array}$ & Male & $\begin{array}{l}\text { Information } \\
\text { Technology }\end{array}$ & GNU & 1 Year \\
\hline P 5 & $\begin{array}{l}\text { Senior } \\
\text { student }\end{array}$ & $\begin{array}{l}\text { Femal } \\
\text { e }\end{array}$ & $\begin{array}{l}\text { Business } \\
\text { Manageme } \\
\text { nt }\end{array}$ & NU & 3 Years \\
\hline P 6 & $\begin{array}{l}\text { Senior } \\
\text { student }\end{array}$ & Male & $\begin{array}{l}\text { Information } \\
\text { Technology }\end{array}$ & NU & 1 Year \\
\hline P 7 & $\begin{array}{l}\text { Senior } \\
\text { student }\end{array}$ & $\begin{array}{l}\text { Femal } \\
\text { e }\end{array}$ & $\begin{array}{l}\text { Humanity\& } \\
\text { Art }\end{array}$ & NU & 2 Years \\
\hline P 8 & $\begin{array}{l}\text { Senior } \\
\text { student }\end{array}$ & $\begin{array}{l}\text { Femal } \\
\text { e }\end{array}$ & $\begin{array}{l}\text { Economic\& } \\
\text { Trade }\end{array}$ & NU & 1 Year \\
\hline P 9 & $\begin{array}{l}\text { Senior } \\
\text { student }\end{array}$ & Male & $\begin{array}{l}\text { Economic\& } \\
\text { Trade }\end{array}$ & GUFE & 1 Year \\
\hline P 10 & $\begin{array}{l}\text { Senior } \\
\text { student }\end{array}$ & Male & $\begin{array}{l}\text { Information } \\
\text { Technology }\end{array}$ & GUFE & 2 Years \\
\hline P 11 & $\begin{array}{l}\text { Senior } \\
\text { student }\end{array}$ & Male & $\begin{array}{l}\text { Humanity\& } \\
\text { Art }\end{array}$ & GUFE & 2 Years \\
\hline P 12 & $\begin{array}{l}\text { Senior } \\
\text { student }\end{array}$ & $\begin{array}{l}\text { Femal } \\
\text { e }\end{array}$ & $\begin{array}{l}\text { Business } \\
\text { Manageme } \\
\text { nt }\end{array}$ & GUFE & 3 Years \\
\hline P 13 & Mentor & $\begin{array}{l}\text { Femal } \\
\mathrm{e}\end{array}$ & Business & GNU & 3 Years \\
\hline
\end{tabular}


INTERNATIONAL JOURNAL OF ACADEMIC RESEARCH ECONOMICS AND MANAGEMENT SCIENCES Vol. 9, No. 3, 2020, E-ISSN: 2226-3624 @ 2020 HRMARS

\begin{tabular}{|c|c|c|c|c|c|}
\hline & & & $\begin{array}{l}\text { Manageme } \\
\text { nt }\end{array}$ & & \\
\hline P 14 & Mentor & $\begin{array}{l}\text { Femal } \\
\text { e }\end{array}$ & $\begin{array}{l}\text { Business } \\
\text { Manageme } \\
\text { nt }\end{array}$ & NU & 8 Years \\
\hline P 15 & Mentor & $\begin{array}{l}\text { Femal } \\
\mathrm{e}\end{array}$ & $\begin{array}{l}\text { Information } \\
\text { Technology }\end{array}$ & GUFE & 5 Years \\
\hline
\end{tabular}

The results obtained in the quantitative analysis section show that the peer input variable has a partial moderating effect on the relationships between the social capital (IE, SI) and innovation capability. Therefore, the Items Cluster function of Nvivo 12 is also used in the qualitative analysis to verify the interaction effect between the variables of the model. The results are shown in figure 7 below.

Figure 7: Items Clustered of Nvivo 12 Software Analysis

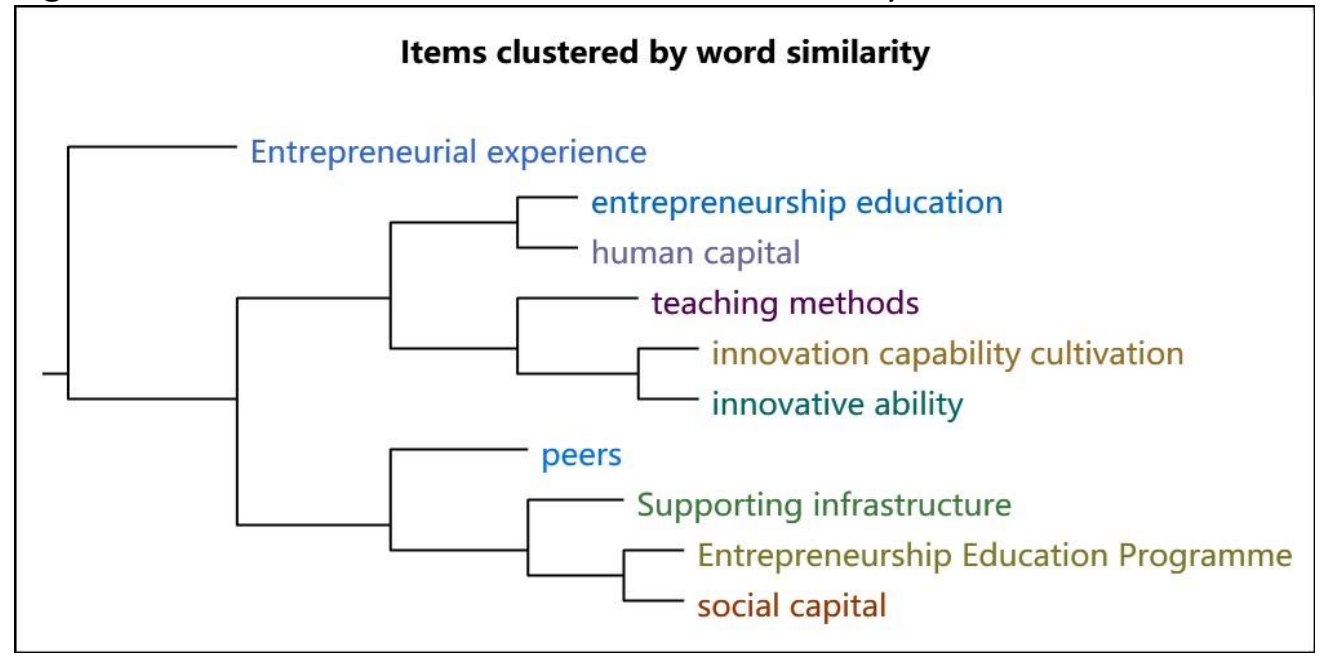

From the above analysis results, we can see that entrepreneurship education and human capital are a cluster, which also indicated that entrepreneurship education can provide human capital for entrepreneurial students. The teaching method is in the same cluster with the innovation ability and the innovation ability, so it can be proved that the interviewees think that the teaching method has a significant influence on the cultivation of student's innovation ability. The peer item is in the same cluster as the entrepreneurship education project, social capital, and supporting infrastructure, which proved that the quantitative analysis of the influence of peer input as a moderating variable is significant. The two clusters formed a large cluster with entrepreneurial experience, which suggested the human capital, social capital generated by university entrepreneurship education and peer input can enhance students' experience in innovative entrepreneurial activities. 
INTERNATIONAL JOURNAL OF ACADEMIC RESEARCH ECONOMICS AND MANAGEMENT SCIENCES Vol. 9, No. 3, 2020, E-ISSN: 2226-3624 @ 2020 HRMARS

Table 5: Explanatory Sequential Design Data Triangulation Presentation

\begin{tabular}{|c|c|c|}
\hline $\begin{array}{l}\text { Quantitative } \\
\text { Analysis Results }\end{array}$ & $\begin{array}{l}\text { Qualitative Follow-up Study - } \\
\text { Interpreting Quantitative Results with } \\
\text { Interviews }\end{array}$ & $\begin{array}{l}\text { How qualitative findings } \\
\text { help explain quantitative } \\
\text { results }\end{array}$ \\
\hline $\begin{array}{l}\mathrm{EEP} \rightarrow \mathrm{IC} \\
\text { H1 not supported }\end{array}$ & $\begin{array}{l}\text { Theme: Entrepreneurship education } \\
\text { program in universities are lack of } \\
\text { practicality. Teachers lack of } \\
\text { entrepreneurial experience. }\end{array}$ & $\begin{array}{l}\text { Practicality, } \\
\text { entrepreneurial experience } \\
\text { emerged as an explanation } \\
\text { content, highlight the } \\
\text { importance of practical } \\
\text { teaching in EE. }\end{array}$ \\
\hline $\begin{array}{l}\mathrm{IE} \rightarrow \mathrm{IC} \\
\text { H2 supported }\end{array}$ & $\begin{array}{l}\text { Theme: Students need support from } \\
\text { universities on institutional policy, } \\
\text { industry practice experience. }\end{array}$ & $\begin{array}{l}\text { Institutional policy, } \\
\text { industry practice } \\
\text { experience emerged as an } \\
\text { explanation content, } \\
\text { highlight the importance of } \\
\text { institutional resource } \\
\text { support. }\end{array}$ \\
\hline $\begin{array}{l}\mathrm{SI} \rightarrow \mathrm{IC} \\
\text { H3 supported }\end{array}$ & $\begin{array}{l}\text { Theme: Students can access } \\
\text { incubation platform resources from } \\
\text { university. Social networks and fund of } \\
\text { entrepreneurial project. }\end{array}$ & $\begin{array}{l}\text { Incubation platform, social } \\
\text { networks emerged to help } \\
\text { explain the importance of } \\
\text { supporting infrastructure. }\end{array}$ \\
\hline 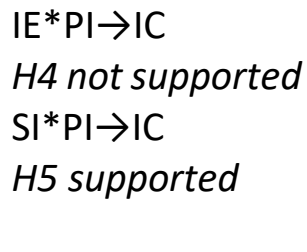 & $\begin{array}{l}\text { Theme: Peer input effect on students' } \\
\text { entrepreneurial intention. Providing } \\
\text { students with entrepreneurial } \\
\text { resource \& experience. }\end{array}$ & $\begin{array}{l}\text { Entrepreneurial intention, } \\
\text { resource \& experience } \\
\text { emerged to help explain } \\
\text { the importance of peer } \\
\text { input. }\end{array}$ \\
\hline
\end{tabular}

In this study, the triangulation method used to discuss the validity of qualitative analysis is a technique often related to reliability and validity in qualitative research. We can improve the validity of the study by triangulation of the results obtained by quantitative and qualitative analysis methods, and use an in-depth description of the research project. Anyone who wishes to transfer the results to another context has the responsibility to judge the validity of this transfer (Creswell et al., 2003).

\section{Conclusion}

The purpose of this mixed-method study is to determine whether the type and degree of support from university entrepreneurship education have an impact on student's innovation capability. To summarize, the results confirmed that entrepreneurship education program has no significant positive impact on innovation capability, while the institutional environment and supporting infrastructure have a significant positive impact on students' innovation capability. Furthermore, it illustrated from the findings that social capital obtained from the institutional environment and supporting infrastructure in entrepreneurial practice has a significant role in promoting innovation capability. The findings of this study also confirmed the current education system and curriculum are not yet mature, teachers are weak, and teaching models are not perfect, which 
have constrained the country's demand for innovative talents (Lu \& Zhang, 2018). The cultivation of innovation capability is a long-term process, and receiving entrepreneurship education is only the starting point of the cultivation of innovation capability, entrepreneurial students need to apply the knowledge with the deepening of entrepreneurial practice activities. Additionally, peer input can help students who lack entrepreneurial experience and practical platform, form networking, inspire and influence student's entrepreneurial intention through their own successful experience and model role (Hendriks, 1999; Yao, 2016).

This study made some contributions to the entrepreneurship education study. First, it has provided new theoretical insights grounded in entrepreneurship education, from the perspectives of human capital and social capital levels influence on innovation capability. Second, a developmental approach that focuses on capital advantage and peer influence is applied in the present study for understanding and ultimately predicting innovative behavior. Finally, an empirical model to develop students' innovation capability is proposed which has practical implications for entrepreneurial education and training in China. In particular, it has important theoretical value to explore and narrow the competitiveness of innovative talents and the economical gap between the east and west of China. This is also meaningful for other developing countries to solve the dilemma of innovation and entrepreneurship development.

This study has implications in several ways, the cultivation of innovation capability includes the construction of the university entrepreneurship education model, the integration of university incubation centers and social industry practice platform. A new normal is a state to which an economy, society settles following a crisis when this differs from the situation that prevailed prior to the start of the crisis. The term has been used in relation to the financial crisis of 2007-2008, the aftermath of the 2008-2012 global recession, and the COVID-19 pandemic (Sandman \& Lanard, 2005). The inflexible and non-practical entrepreneurship education, unable to adapt to the new normal economy and national innovation strategy demand, and even inhibit student's innovative entrepreneurial capability.

Contextually, government and university policy makers are encouraged to develop an innovationdriven entrepreneurship education model, including constructing innovative talent cultivation networks with government and social industry (entrepreneurship education programs, institutional ecological environments, supporting incubation facilities). Specifically, establishing entrepreneurship as a professional subject and set up an independent entrepreneurship teaching and research office, strengthen teacher training in cooperation with enterprises, adopt the mixed teaching method of online and offline, reinforce investment and construction of supporting infrastructure, encourage students to participate in entrepreneurial associations and hold on the entrepreneur's alumni seminars. The innovation-driven entrepreneurship education model recommended by this study is shown in figure 8 below. 
Figure 8: The Process of Innovation-driven Entrepreneurship Education

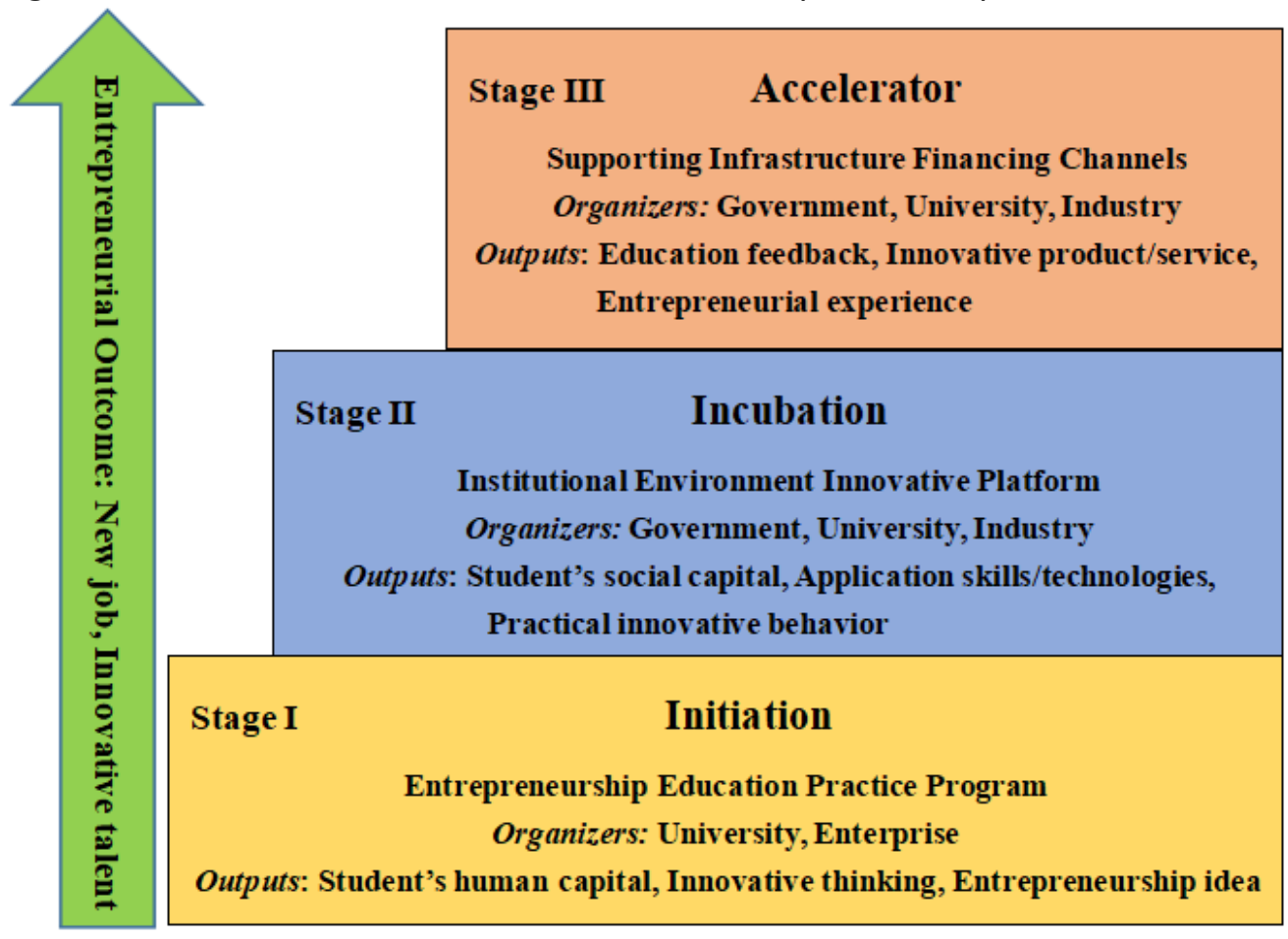

Because of the limitations of pandemic, this study used online questionnaires and interview. since the target population was a senior student at a full-time university in china, the accessible sample might not represent the entire population. Thus, future research should include more universities and different groups in China's different geographical location, socioeconomic status. Additionally, in accordance to Lu\&Zhang (2018) investigations suggested that current education system and curriculum are not yet mature, teachers are weak, and teaching models are not perfect, which have constrained the country's demand for innovative talents. There are many antecedents of innovation capability, further research should investigate which important factors of private sector and public sector can affect innovation capability. In particular, the possible impact of peer input on the relationship between entrepreneurship education and innovation capability.

\section{References}

Ajzen, I. (1991). The theory of planned behavior. Organizational Behavior and Human Decision Processes, 50(2), 179-211.

Aldrich, H., \& Zimmer, C. (1986). Entrepreneurship through social networks. California Management Review, 33(3), 3-23.

Alex, M., \& Chris, B. (2010). A blended learning approach to entrepreneurship education. 2010 ICOI Proceedings, Actual Problems of Economics.

Almaskari, H. T., Mohamad, E., \& Yahaya, N. S. (2020). The development of innovation capabilities. A review paper about the challenges and future research trend in the UAE high education. TEST Engineer \& Management, 83(2), 7299 - 7307. 
Bergmann, H., Hundt, C., \& Sternberg, R. (2016). What makes student entrepreneurs? On the relevance (and irrelevance) of the university and the regional context for student startups. Small Business Economics, 47(1), 53-76.

Bae, T. J., Qian, S., Miao, C., \& Fiet, J. O. (2014). The relationship between entrepreneurship education and entrepreneurial intentions: a meta-analytic review. Entrepreneurship Theory \& Practice, 38(2), 217-254.

Bruyat, C., Julien, P. A. (2001). Defining the field of research in entrepreneurship. Journal of Business Venturing, 16(2), 165-180.

Cinar, E. M., Du, Y., \& Hienkel, T. (2018). Chinese entrepreneurship attributes: a comparative GEM data analysis. Journal of Entrepreneurship in Emerging Economies, 10(2), 217-248.

Christensen, C. M., Bartman, T., \& Van Bever, D. (2016). The hard truth about business model innovation. MIT Sloan Management Review, 58(1), 31.

Cope, J., \& Watts, G. (2000). Learning by doing-an exploration of experience, critical incidents and reflection in entrepreneurial learning. International Journal of Entrepreneurial Behavior \& Research, 6(3), 104-124.

Creswell, J. W. (2003). Research design: Qualitative, quantitative and mixed methods approaches. (2nd Ed.). Thousand Oaks, California: Sage.

De Jong, J., \& Den Hartog, D. (2010). Measuring innovative work behaviour. Creativity and innovation management, 19(1), 23-36.

Fayolle, A. (Ed.). (2007). Handbook of research in entrepreneurship education: A general perspective (Vol. 1). Cheltenham, UK: Edward Elgar Publishing.

Fetters, M., Greene, P. G., \& Rice, M. P. (Eds) (2010). The Development of University-Based Entrepreneurship Ecosystems: Global Practices. Northampton, MA: Edward Elgar Publishing.

Gatewood, E. J., Shaver, K. G., \& Gartner, W. B. (1995). A longitudinal study of cognitive factors influencing start-up behaviors and success at venture creation. Journal of Business Venturing, 10(5), 371-391.

Hua, Z., Yang, J., \& Coulibaly, S. (2006). Integration TRIZ with problem-solving tools: a literature review from 1995 to 2006. International Journal of Business Innovation and Research, 1 (1-2), 111-128.

Henry, C., Hill \& F., Leitch, C. (2005). Entrepreneurship education and training: can entrepreneurship be taught? Part I. Education+ Training, 47(2), 98-111.

Honig, B. (2001). Learning strategies and resources for entrepreneurs and intrapreneurs. Entrepreneurship Theory and Practice, 26(1), 21-34.

Ismail, M. (2005). Creative climate and learning organization factors: their contribution towards innovation. Leadership \& Organization Development Journal, 26(8), 639-654.

Kraaijenbrink, J., Bos, G., \& Groen, A. (2009). What do students think of the entrepreneurial support given by their universities? International Journal of Entrepreneurship and Small Business, 9(1), 110-125.

Leitch, C., Hazlett, S. A., \& Pittaway, L. (2012). Entrepreneurship education and context. Entrepreneurship \& Regional Development, 24(9-10), 733-740.

Lu, Y., \& Tang, M. F. (2014). Does Chinese university entrepreneurship education fit students' needs? Journal of Entrepreneurship in Emerging Economies, Emerald Group Publishing. 
Martin, B. C., McNally, J. J., \& Kay, M. J. (2013). Examining the formation of human capital in entrepreneurship: A meta-analysis of entrepreneurship education outcomes. Journal of Business Venturing, 28(2), 211-224.

Maxwell, J. A. (2005). Conceptual framework: What do you think is going on? In Qualitative research design: An interactive approach (3rd ed.). Los Angeles, CA: Sage.

Nabi, G., Linan, F., Fayolle, A., Krueger, N., \& Walmsley, A. (2017). The impact of entrepreneurship education in higher education: A systematic review and research agenda. Academy of Management Learning \& Education, 16(2), 277-299.

Preeti, T. (2020). Impact of Covid-19 pandemic on education system. International Journal of Advanced Science and Technology, 29(9), 3812-3814.

Pittaway, L. A., Gazzard, J., Shore, A., \& Williamson, T. (2015). Student clubs: experiences in entrepreneurial learning. Entrepreneurship \& Regional Development, 27(3-4), 127-153.

Rae, D. (2002). A narrative study of entrepreneurial learning in independently owned media businesses. The International Journal of Entrepreneurship and Innovation, 3(1), 53-59.

Mwasalwiba, S. E. (2010). Entrepreneurship education: a review of its objectives, teaching methods, and impact indicators. Education+ Training, 52(1), 20-47.

Scott, W. R. (2008). Institutions and organizations: ideas and interests. Los Angeles, CA: Sage Publications.

Solomon, G. (2007). An examination of entrepreneurship education in the United States. Journal of Small Business and Enterprise Development, 14(2), 168-182.

Van de Ven, A. H. (1989). Using paradox to build management and organization theories. Academic of Management Review, 14(4), 562-578. 